\title{
An Analysis of Factors Influencing College Students' Employment Security-Taking a University as an Example
}

\author{
Yang Weibo and Luo Kui \\ Department of Student Affairs, Wuhan University of Technology, Wuhan, P.R. China, 430070 \\ Department of Data Mining, FrontSurf, ShenZhen, P.R. China, 518101 \\ yangwb@whut.edu.cn,510711457@qq.com
}

Keywords: Employment security, University factors, Social factors, Students' factors

\begin{abstract}
The employment security of college students is closely related to economic development, talent cultivation, social harmony and stability. At present, college students' employment is characterized by diversification of the approaches for seeking jobs, the lack of employment security awareness and knowledge about employment laws and regulations, the severe employment security situation and so on. By means of quantitative study, this paper aims to analyze the factors that influence college students' employment security, such as students' factors, university factors and social factors. It is found that social factors, the grade and comprehensive performance rankings have marked impacts on the employment security of college students, while the others make little difference. This result will provide a scientific basis for university employment security education as well as security monitoring and promote resource allocation optimization of university employment security work, so as to provide better services for students.
\end{abstract}

\section{Introduction}

In recent years employment pressure of college graduates has been increasing together with their numbers. Under the new employment system, socialization and marketization of college students employment has also been further improved. The employment market is broaden and the ways of publishing employment information are also diversified, which, however, has made the employment security problems become more and more prominent.[1] The problems of college students' employment security are related to their high employment expectations. Regardless of the differences between professional ideals and social reality, some college students who are full of dreams for future career tend to be tempted by high salary and welfare, so as to result in many employment security issues.[2] In addition, the college students' employment security is also closely related to economic development, the cultivation of talents as well as social harmony and stability. Nowadays, college students' employment shows many characteristics, such as the diversification of approaches for seeking jobs, the lack of employment security awareness and knowledge about employment laws and regulations, the severe employment security situation and so on. In order to ensure and promote college students employment security, the management and supervision should be strengthened.

The previous researches has concluded a great number of factors that influence college students' employment security. For example, Gu(2014) [3] pointed out that college students' employment security were mainly due to the lack of security guarantee of employment information, the imperfection of relevant laws and regulations as well as the inefficiency of employment security education. Then they put forward some measures, such as strengthening the supervision of employment information, speeding up the establishment of legislation system of college students' employment, intensifying the management and supervision of employment security in various aspects as well as innovating the educational model of employment security. It was also discussed by other researchers from the perspective of personal security, information security, economic security and psychological security. In terms of safety education, employment regulation and college management, the reasons for employment security problems were discussed as well (Shen Jing, 2014)[4]. 
By analyzing the employment traps, employment environment and other factors, Cui (2013)[5] elaborated employment security problems. He put forward the idea that the governments, universities and enterprises work together for college students' employment security which was of great practical significance for college students' rational and high-quality employment. Zhao (2014)[6] set up a security evaluation index system of college students employment situation through the study. It was based on the pressure-state-response model of the relationship between human beings and the nature which is established by OECD, and tried to provide basic information for college students' employment study by assessing the relationship among various components, to build a multi-level evaluation index system. Some researches found that for the students who were faced with great pressure of poverty and employment, they always bore great mental stress and their employment security problems were more serious. Without proper guidance, security risks tended to exist among such students. So more attention should be paid to them (Yang Jun, 2013)[7]. This paper introduces the situation of such students and discusses the solutions by analyzing the causes of employment predicament. However, these students are just a small part of the graduates, other students are also faced with employment security problems.

It can be found from above researches that most of the solutions are theoretical guidance and it is difficult to know which students are most likely to be confronted with employment security problems. For instance, it still remains unknown whether the gender, major and grade influence students' employment security, or how those relevant factors influence the employment security. So it is necessary to collect students' employment information and data to find out the potential internal relations. Only when we figure out the relationship among the factors that affect the students' employment and the specific students can university employment guidance center invest resources to solve the problems with plans. Here quantitative study is applied to figure out whether college students' personal factors, universities' factors, and social factors will influence students' employment security. This result will provide a scientific basis for university employment security education and security monitoring, so as to optimize resource allocation of university employment security work and provide better services for students.

\section{The Analysis of Questionnaires}

The subjects of this research are the students of one university administrated by the Ministry of Education in Wuhan. The investigation was carried out through SO JUMP-a platform for questionnaire survey. A total of 924 valid questionnaires were got, among which there were 549 male students (accounting for 59.4\%) and 375 female students (40.6\%); 294 were senior students (31.8\%), 122 postgraduates in grade three (13.22\%), 425 graduated students (46.0\%) and 83 other students $(9.0 \%)$. Based on previous relevant researches, this study makes a conclusion of the employment security problems that college students encounter. 9 problems are got in total (see Table 1). The scale uses the 0-1 dummy variable to measure whether college students have experienced the employment security issues. 0 represents no and 1 is yes. Under the correlation and regression analysis, according to previous study (Guthrie, 2001)[8], the degrees of employment security problems college students experience are measured with a continuous variable, which is to add up 9 variables scores. The higher the final score is, the more serious the security problems are. Factors that might influence college students' employment security are concluded from 4 aspects: the demographics of college students, college students' personal factors, university factors and social factors. Measured by quite professional scale, the questionnaires are of good reliability and validity.

In the study of college students' employment security problems, it is found that (see Table 1) "the employers obtaining cheap labor force in the name of probation" has become the most serious problem, which has bothered $68.1 \%$ of the subjects. "Disclosing too much personal information resulting in illegal harassment" ranks in the second place, and $51.5 \%$ choose this option, which shows that the security problems caused by information leakage during job hunting can not be ignored as well. In addition, "the employers issuing false recruitment information" takes up a proportion of 39.3\%. The three items above as the most serious employment security problems faced by college students need to be taken seriously. As for "the employers being the pyramid selling organizations", only $11 \%$ of the subjects think it as a 
problem, indicating that it is of low probability to come across pyramid selling organization, but it also need to be paid close attention to. What's more, there are still some other employment security problems, as shown in Table 1.

\section{Table 1 The Summary of Employment Security Problems for College Students}

\begin{tabular}{|c|c|c|}
\hline Employment security problems & $\begin{array}{l}\text { Percentag } \\
\mathrm{e}\end{array}$ & $\begin{array}{l}\text { The Percentage } \\
\text { Individual Case }\end{array}$ \\
\hline $\begin{array}{l}\text { The employers obtaining cheap labor force in the name of } \\
\text { probation }\end{array}$ & $23.0 \%$ & $68.1 \%$ \\
\hline $\begin{array}{l}\text { The employers collecting margin or training fees in the improper } \\
\text { name }\end{array}$ & $10.4 \%$ & $30.8 \%$ \\
\hline The employers issuing false recruitment information & $13.3 \%$ & $39.3 \%$ \\
\hline $\begin{array}{l}\text { The intermediary collecting money without providing } \\
\text { appropriate jobs }\end{array}$ & $11.0 \%$ & $32.7 \%$ \\
\hline The employers being the pyramid selling organization & $3.7 \%$ & $11.0 \%$ \\
\hline $\begin{array}{l}\text { The employers refusing to sign the employment agreement or }{ }_{126} \\
\text { contract }\end{array}$ & $7.2 \%$ & $21.4 \%$ \\
\hline $\begin{array}{l}\text { Disclosing too much personal information resulting in } \text { illegal }_{304} \\
\text { harassment }\end{array}$ & $17.4 \%$ & $51.5 \%$ \\
\hline $\begin{array}{l}\text { Your or your classmates' experience of being cheated by paying } 124 \\
\text { to someone to find a job }\end{array}$ & $7.1 \%$ & $21.0 \%$ \\
\hline $\begin{array}{l}\text { Being dismissed after the registration for no reason or for a bad } \\
\text { excuse }\end{array}$ & $6.8 \%$ & $20.2 \%$ \\
\hline Total & $100.0 \%$ & $296.1 \%$ \\
\hline
\end{tabular}

Table 2 Correlation Analysis among the Variables

\begin{tabular}{|c|c|c|c|c|c|c|c|c|c|c|c|}
\hline & 1 & 2 & 3 & 4 & 5 & 6 & 7 & 8 & 9 & 10 & $11 \quad 12$ \\
\hline Employment security & 1 & & & & & & & & & & \\
\hline Students' factors & $.144^{* *}$ & 1 & & & & & & & & & \\
\hline University factors & $.172^{* *}$ & $.451^{* *}$ & 1 & & & & & & & & \\
\hline Social factors & $.239^{* *}$ & $.575^{* *}$ & $.621^{* *}$ & 1 & & & & & & & \\
\hline Gender & .007 & .060 & $.074^{*}$ & $.069^{*}$ & 1 & & & & & & \\
\hline Grade & -.038 & $.119^{* *}$ & .058 & $.119^{* *}$ & .060 & 1 & & & & & \\
\hline Political status & -.055 & -.044 & .055 & .009 & $-.122^{* * *}$ & $-.070^{*}$ & 1 & & & & \\
\hline Cadre experience & .025 & .037 & .057 & .040 & $.140^{* *}$ & .046 & $-.299^{* *}$ & 1 & & & \\
\hline Comprehensive score ranking & $-.073^{*}$ & .009 & .020 & .034 & $-.167^{* *}$ & $-.126^{* *}$ & $.351^{* *}$ & $-.161^{* *}$ & 1 & & \\
\hline Foreign language level & .025 & -.002 & -.035 & .020 & $.157^{* *}$ & $.071^{*}$ & -.050 & .052 & $-.199^{* *}$ & 1 & \\
\hline Major & .006 & .035 & $.068^{*}$ & $.073^{*}$ & $.324^{* *}$ & $.113^{* *}$ & .036 & $.116^{* *}$ & .040 & $.153^{* *}$ & 1 \\
\hline Graduate destination & -.041 & $-.094^{* *}$ & -.029 & -.030 & -.051 & .009 & $.091^{* *}$ & -.046 & $.208^{* *}$ & $.073^{*}$ & .0411 \\
\hline
\end{tabular}


Table 3 Regression analysis of employment security

\begin{tabular}{lllll}
\hline & \multicolumn{2}{l}{ Dependent Variable: } & Employment Security & \\
& $\mathrm{B}$ & $\mathrm{SD}$ & \multicolumn{2}{l}{ T-value P-value } \\
\hline (Constant) & .287 & .665 & .431 & .666 \\
Gender & -.134 & .155 & -.865 & .387 \\
Grade & -.173 & .070 & -2.453 & .014 \\
Politics status & -.156 & .136 & -1.147 & .252 \\
Cadre experience & -.029 & .165 & -.177 & .860 \\
Comprehensive score ranking & -.168 & .079 & -2.138 & .033 \\
Foreign language level & .045 & .098 & .458 & .647 \\
Major & .012 & .048 & .244 & .807 \\
Graduate destination & -.049 & .110 & -.448 & .655 \\
Students' factors & .016 & .124 & .132 & .895 \\
University factors & .109 & .107 & 1.015 & .310 \\
Social factors & .689 & .139 & 4.952 & .000 \\
\hline
\end{tabular}

Correlation analysis shows that (see Table 2). Taking gender, grade, politics status, Cadre experience, score ranking, foreign language level, major, graduate destination, students' factors, University factors as well as social factors as independent variables and choosing the employment security as dependent variable to make regression analysis, the results are shown in Table 3. The grade of students has a huge negative influence on employment security. The influence coefficient is -0.173 , which suggests that students in the lower grades are more likely to be confronted with employment security problems. The score ranking has a significant negative impact on employment security. The impact coefficient is -0.168 , which shows that students with lower scores are more likely to encounter employment security problems. Social factors have a significant positive impact on employment security. Its impact coefficient is 0.689 , which indicates that the weaker the social regulation for employment environment is, the more serious the problems will be. Other factors make little difference to college students' employment security.

\section{Discussion}

Three most serious problems of college students' employment security are got by study. The first one is "the employers obtaining cheap labor force in the name of probation" which is the most serious one among the three problems. Many enterprises as employers offer quite low wages and benefits to college students during their probation, making them become cheap labor force. In order to create a good employment environment, employers should regulate their own employment behavior, and at the same time it takes the joint efforts of the government and society to supervise the employment environment. The second serious problem is "disclosing too much personal information resulting in illegal harassment". To find a job as soon as possible, some students disclosure their personal information freely without detailed investigation about the background of the recruitment enterprises. Illegal harassment tends to occur for the students who have freely provided the employers with their personal phone number, their parents' names, as well as their family addresses, and those who have lost their resumes (Kou,2009)[9]. The third serious problem is "the employers issuing false recruitment information". In order to recruit excellent employees, some enterprises may exaggerate the wages and benefits they can provide. When the students become their staff, they can not offer the promised benefits. There are also some enterprises cheating students with false information. To avoid security problems, it requires students to investigate background information of the businesses during their job hunting. At the same time, the colleges and universities should make sure that the recruitment enterprises are reliable, so as to provide high-quality recruitment information for students. The subjects of this investigation and survey are form one famous university administrated by the Ministry of Education. The comprehensive quality of students and recruitment enterprises is relatively higher, so the employment security problems are not so serious, which also results from the high attention paid by the college employment center to college students' employment. 


\section{Conclusion}

The guidance for college students' employment security provided by previous studies are always theoretical. It is difficult to know which students are most likely to be confronted with employment security problems. In this research, quantitative method is adopted to figure out the most important issues of employment security, and it is found that the grade, comprehensive score ranking and social factors have greatly influenced the employment security problems. This result will provide a scientific basis for university employment security education and security monitoring, so as to optimiz e resource allocation of university employment security work and provide better services for students.

\section{References}

[1] Zhai Yunqiu. The Study of College Students' Employment Security and Countermeasures [J]. The Journal of Hunan Industry Polytechnic, 2014, 14 (5): 102-104 (In Chinese)

[2] Zhang Jiyan, Bai Zepu. The Study of Employment Security Problems of College Students. Higher Agricultural Education, 2010, 7(7):86-87 (In Chinese)

[3] Gu Hongxin, Wang Jinyue, Gao Nan, Zhang Jiushi. The Study of College Students' Employment Security and Countermeasures[J]. Theory and Practice of Education, 2014, 34(30): 18-19 (In Chinese)

[4] Shen Jing. The Analysis of the Current Situations and Causes of College Graduates' Employment Security [J]. The Journal of Hubei University of Education, 2014, 31(5): 76-79 (In Chinese)

[5] Cui Ze. The Employment Security of College Graduates [J]. The Journal of Chifeng University (Natural Science Edition), 2013, 29 (8): 253-254 (In Chinese)

[6] Zhao Haixiao. The Study on the Evaluation Index System of College Students' Employment Security [J]. Education Theory \& Practice, 2014, 34(15): 12-14 (In Chinese)

[7] Yang Jun. The Discussion and Analysis of the Disadvantaged Reasons for the Employment of Graduates with "Double Difficulties" [J]. The Journal of Hubei Adult Education Institute, 2013, 19, (3): 44-46 (In Chinese)

[8] Guthrie J P. High Involvement Work Practices Turnover and Productivity: Evidene from New Zealand [J] .Academy of Management Journal, 2001, 44 (1): 89-109 (In Chinese)

[9] Kou Quanqiang, Tang Xiao, Chen Lili. The Analysis of College Students' Employment Safety and the Coping Strategies [J]. The Journal of Henan Vocational \& Technical Teachers College (Vocational Education Edition), 2009 (3) (In Chinese) 